\title{
'Arca, archivillo, archivo': the keeping, use and status of historical documents about the Spanish Conquista
}

\author{
Arndt Brendecke
}

Published online: 2 October 2010

(C) Springer Science+Business Media B.V. 2010

\begin{abstract}
Developing a relativistic concept of the pre-modern archive, this article considers the relationship between knowledge inside and outside the archive to determine how Spain's historical documents about its new American territories were kept and used. The starting assumption is that collections of documents about the Spanish Conquista circulated among people and were not permanently stored within fixed archival spaces, such as small lockable cases (arcas), private collections of documents (archivillos), or the actual state archives (archivos). This article thus re-evaluates the state of knowledge about the new American territories of Spain and its distribution across various archives and collections. It draws particular attention to the use of historical documents by official chroniclers of Spain and historians of the Conquista of the Spanish Americas.
\end{abstract}

Keywords Early modern archives · Spain - Simancas · Court historiography · Latin America in Spanish archives

From the perspective of the history of knowledge, archives represent a particularly interesting object of study. In them, a social interest in 'knowing' seems to take a notably concrete form. Yet early modern archives unwillingly reveal their own lack of use, as well. In the words of the Spanish poet Félix Lope de Vega (1562-1635), "To be like writings in an archive" meant nothing else than to be worthless or dead. ${ }^{1}$

${ }^{1}$ Lope de Vega, El enemigo engañado, cited in Navarro Bonilla (2003, p. 95).

A. Brendecke $(\bowtie)$

Geschichte und Kulturen Lateinamerikas, Historisches Institut der Universität Bern,

University of Bern, Länggassstrasse 49, 3000 Bern 9, Switzerland

e-mail: arndt.brendecke@ hist.unibe.ch 
The knowledge that shaped pre-modern political and social praxis must doubtless be sought primarily outside of libraries and archives. Such knowledge was carried by persons, was guarded and transmitted by families, workers, and guilds, was constituted through conversations at table or in court, and remained embedded in practices that scarcely required written form. ${ }^{2}$ In contrast, archives and libraries remain marginal phenomena for the history of knowledge, whose significance emerges only as one analyzes to what extent they shaped the epistemic environment of some political figure or historical writer during the pre-modern age. For such purposes, moreover, the relationship between knowledge within and without the archive must be determined, not simply in quantitative terms but rather in respect to their status and their operative significance within everyday politics. Taking such a relativistic approach to the concept of the archive does not demean the institution. Rather, this approach can contribute to distinguishing the reality of the pre-modern 'archive' from its ideal. Not its distance from the goal of a smoothly functioning, public and well-ordered archive is of primary interest, but the contemporary spectrum of practices and interests that surrounded and penetrated the archive.

In this essay, I assess knowledge about the new American territories of Spain and its distribution across various archives and points of collection. Doing so requires close attention to situations outside the archive: which papers in an archive became 'hot' - that is, politically significant — depended on events beyond the walls of the repository. This approach therefore requires engaging with a wider topography in which the archive constituted only one piece in the game. The battle over memory took place mainly at court, for example. Entangled with the dynamics of friendship and patronage, memory colluded with the work of court historiography and resorted to a wide variety of documentary genres stored in the desks of secretaries and the houses of royal councilors. My analysis therefore seeks to dissolve the 'archive' as a monolithic, closed presence, and to work out a few precisely describable scenarios played out across both sides of its walls. A key starting presumption will be that in pre-modern situations discrete assemblages of documents circulated together with people, rather than already resting within fixed archival spaces. Actual archives represented only a single point on a scale that also included the small (and often uncontrolled) collections of minute polities, the contents of desks, and private chests of documents. To introduce the contemporary Spanish categories, the small lockable case (arca), the private collection of documents (archivillo), and the actual state archive (archivo) existed in parallel, and such parallelism constituted the starting point for early modern archive use.

\section{The utopia and reality of a Spanish central archive}

In 1555, the royal chronicler Juan Páez de Castro submitted a memorial to the young king Philip II in Brussels that proposed creating an ideal site of knowledge. ${ }^{3}$ Páez

\footnotetext{
${ }^{2}$ Concerning private archives in early modern Spain, see Navarro Bonilla (2004).

3 Biblioteca del Monasterio de El Escorial, Ms. \&. II. 15, 7, fol. 190a-195a, edited as: Páez de Castro (1883).
} 
imagined an edifice that would transcend by far a mere library or archive. He suggested erecting his new knowledge center in Valladolid - at this point still one of the court's seats-in a building that would contain three large halls. The first would contain all manner of books and serve as an "oracle on all matters in doubt." 4 The second cosmographical hall took a more unusual form. Here, Páez intended to place not only large-format maps of the lands and seas in every part of the world but also globes, models of scientific instruments and military machines, clocks, genealogies, and painted metal models of trees, herbs, and fruits. ${ }^{5}$

The third hall would serve as the archive and constituted the most secret part of the collection. It would contain not only charters but also documents pertaining to everyday matters in the colonial empire, such as lists of encomiendas, along with political reports from Europe and the Americas. ${ }^{6}$ Páez argued that it would be simple to gather the documents for the planned archive, since they already rested in palace archives and storage rooms, in the possession of the secretaries, or at the Consejos and chanceries. Seeking to engage Philip's interest and to emphasize the project's value, Páez compared the planned contents of this new archive located at the court to the presence of especially well-behaved courtiers who would speak only when asked a question — and would respond only with relevant information. ${ }^{7}$

One omission is noteworthy: Castile at this point already possessed a central archive that was not mentioned in Páez's project, namely the archive at Simancas founded by Philip's father Charles V in 1540. This facility's location in a defensible castle well removed from the kingdom's major cities is generally explained by the experience of the Comunero revolt of 1520-21, during which many valuable charters had been destroyed. Simancas was consequently optimized for protecting documents, not for their use. The Simancas archive received its first archivist, Diego de Ayala, in 1561 - the same year the Spanish court settled permanently in Madrid, nearly $200 \mathrm{~km}$ away - and a comprehensive set of regulations in 1588 (Instrucción 1989). During Philip's reign, the castle at Simancas experienced several major remodelings that brought the architecture of the building into conformity with the topography of the Spanish empire. For example, documents pertaining to the American territories came to rest in the cabinets and boxes of the Sala de Indias. Philip's own ideas concerning the proper management of archives evolved further through his experiences in Lisbon, where he held court from 1581 to 1583 after the union of the Spanish and Portuguese crowns. The Torre de Tombo archive in Lisbon collected not only royal documents but also a much wider range of charters related to the lords and vassals of the entire kingdom. A memorial submitted to Philip in 1584 highlighted the benefits of this approach: if everyone who wished to do so could deposit his papers in a central archive, then he also would contribute to the defense of the archive in case of a rebellion (Instrucción 1989, p. 465). Rather than relying on strong walls to protect the archive, as Charles V had intended, the very

\footnotetext{
${ }^{4}$ Cf. Biblioteca del Monasterio de El Escorial, Ms. \&. II. 15, fol. 192v; edited as: Páez de Castro, Memorial, 171.

5 Biblioteca del Monasterio de El Escorial, Ms. \&. II. 15, fol. $193^{\mathrm{r}}$.

${ }^{6}$ Biblioteca del Monasterio de El Escorial, Ms. \&. II. 15, fol. 193 ${ }^{\mathrm{v}}-194^{\mathrm{r}}$.

7 Biblioteca del Monasterio de El Escorial, Ms. \&. II. 15, fol. 194 $-194^{\mathrm{v}}$.
} 
permeability of those walls for a wide range of parties would guarantee the material's safety. This approach, however, set into motion an entirely different 'constitution' of the archive, one that rested on a consensus of interest among all those who desired institutionally founded legal security and for whom the archive would provide a third depository site for their legal titles. Early modern states rested on a regime of privileges that created permanent subject-oriented legal conditions through arbitrary acts on the part of rulers. The validity of such privileges remained permanently precarious, however, as long as the titles awarded to individual holders depended on only two copies, namely a single charter issued to the recipient and a single chancery registry at court. In addition, even matters of private law could profit from the existence of a public archive. A 1631 memorial published in Madrid proposed an 'archive of public writings' that would contain complete transcriptions of all documents issued by public notaries as well as their registers. Anyone could then locate the transcript of a public contract if he remembered, for example, the name of the issuing notary and the year. ${ }^{8}$

Was it then primarily private parties who were interested in this new type of archive? Investigations of how Simancas was used in the sixteenth century confirm this hypothesis. Some 600 requests for documents reached the archive during the late sixteenth century, of which only thirty-five came from the king and another 112 from nobles. Private parties (particulares) without official or noble titles used this facility more than any other group, in contrast, requesting copies in 154 cases (Instrucción 1989, p. 473).

Thus, even though Simancas retained a strong patrimonial function tied to the legal prerogatives of the crown, it also remained open to 'private' interests. Never, however, did Simancas become a site of contemplation and decision of the kind envisioned by the humanist intellectual Páez de Castro. Even lighting and heating was forbidden in the archive, because of fear of fire. Simancas thus remained quite literally 'cold'.

Let us therefore turn to the pathways leading into or out of the archive (Navarro Bonilla 2003, p. 101). The following discussion will first address the acquisition of materials for Simancas and then turn to the use of Simancas materials in various historiographical enterprises.

\section{Arca, archivillo, archivo: the topography of accumulations}

The first archivist at Simancas, Diego de Ayala, spent years in search of documentary deposits suitable for transfer to Simancas. He poked into musty cellars, presented himself before the heirs of deceased state secretaries, ordered inventories of living secretaries' desks to be made, and even came into conflict with the Jeronymite monastery at the Escorial, whose construction the king had just ordered. Whereas the monks sought to retain the founding charters of the new establishment, since these would also allow them to protect their privileges, Ayala

\footnotetext{
${ }^{8}$ Cf. Arquivo Nacional da Torre do Tombo (Portugal), Casa Cadaval: L. 25, Ms. 572, fol. 380 $-380^{\mathrm{v}}$ : Xarava [de Castillo] sobre que se haga Archivo de las escrituras publicas, Madrid, 2 June 1631.
} 
insisted in the name of the king that at least the registers of the monks' relics and other inventories be deposited in Simancas. In his discussions directly with the king, Ayala argued that collecting the largest possible number of documents at Simancas would forestall the creeping loss of the crown's legal titles. In addition, the 'vassals' would benefit as well, since good order in the archive would help prevent the 'daily' lawsuits that resulted when necessary registers could not be located. ${ }^{9}$ Ayala summed up his case in a memorial dated July 18, 1577: "indeed, my business is the keeping of governmental papers and royal rights, and I hold it to be no less important or less necessary than others." 10

The challenges and delays that Ayala encountered in his efforts to requisition documents at court and transfer them to Simancas speak a different language, however. Simancas's acquisition of documents took place in waves and for diverse reasons. The recogimiento general de papeles of 1572 occurred because the king was upset when he could not find the documents needed to exert his patronage rights over churches. As a result, depositories and archives in Burgos, Oviedo, Valladolid, Valencia, Toledo, and Rome received visits, and various documents moved to Simancas. In 1573, Ayala visited the court in Madrid, where he encountered particular difficulty in prying documents away from the political councils. In the end, Ayala left for Simancas with 120 cases of material, but it consisted only of records from the Contaduría de Cuentas, a few secretariats, and the Council of the Indies (which had been responsible for the American business of the Spanish Empire since the 1520s). Another report from 1577 records the transfer of some one and a half tons of documents from Madrid to Simancas in carts. ${ }^{11}$

As already observed for the Escorial, central collection of documents competed with other parties who had an interest in the same material. Additionally, the constantly repeated call for protective custody ("conservar") of documents should not be equated with a modern concept of long-term preservation and availability. In one of his memoranda, for example, Ayala noted that he had found a small chest (arquilla) of documents in the possession of a certain doctor Velasco that was full of theological documents about the legality of the war that Spain had carried out against Pope Paul IV. According to Ayala, such documents should not "circulate outside the archive." 12 Archives could thus serve as secure sites of forgetting, to which one dispatched texts that were neither necessary for daily political affairs nor suitable for unrestricted circulation (Navarro Bonilla 2003, pp. 95-106).

The archive's function of keeping remote collections permanently inaccessible takes on more concrete contours when examining documentary holdings relating to the American territories. The Council of the Indies possessed its own council archive, though in the sixteenth century this probably consisted only of several cases and lockable chests, and did not yet have its own assigned room. Locking up papers in these chests was not, however, a sign of high value. Over and over, pieces entered

\footnotetext{
9 Instituto Valencia de Don Juan (Madrid), envío 16, fol. $58^{\mathrm{r}}$.

${ }^{10}$ Instituto Valencia de Don Juan (Madrid), envío 16, fol. $64^{\mathrm{r}}$.

11 Instituto Valencia de Don Juan (Madrid), envío 16, doc. 59; Instituto Valencia de Don Juan (Madrid), envío 16, doc. 16, 28 June 1577.

12 Instituto Valencia de Don Juan (Madrid), envío 16, doc. 57.
} 
the council archives that one did not want to circulate beyond the council, even though they no longer had any value to the council itself. For example, Diego de Zorrillas's nine-volume codification of colonial law was prepared for printing at the beginning of the seventeenth century, but displeased the council. Instead of being presented to the king for publication, it was transferred directly into the council's archive, with the result that the manuscript has remained unlocatable up to the present (Manzano Manzano 1973, pp. 14-15).

Thus, although the council archive was integrated directly into the council, it possessed little operative significance for the council's daily business. On the contrary, all documents of actual value or use quickly left the archive in various directions. First, members of the council, including the presidents, secretaries, scribes, and also the chroniclers, formed 'wild' document collections, the so-called archivillos, in their private residences in the course of their service, even against explicit royal instructions. Most of what was collected in such archivillos became visible only upon their deaths, when the inventory of their estates was compiled (Bouza Álvarez 1996/97, p. 9; Bouza Álvarez 2001, pp. 241-248; Navarro Bonilla 2003, p. 139). ${ }^{13}$ Second, as the secretariats of the Council of the Indies developed further in the seventeenth century, the individual secretaries increasingly gathered to their own offices those documents, registers, and other guides to the collection that were necessary for everyday administration. Finally, older material was removed in multiple waves and transferred to the archive in Simancas. In this way, both operationally valuable and historically significant material steadily departed from the council's archive, to the extent that an attempted reform of the archive in 1709 found only three chests containing a few bulls, briefs, and notices (Gómez Gómez and González Ferrín 1992, pp. 191-192).

The first documented transfer of material from the Council of the Indies to the archive in Simancas already took place in $1544 .{ }^{14}$ At first, the necessary journeys to Simancas were the responsibility of the porter, but later the staff of the secretariats also carried them out. ${ }^{15}$ Specially designed crates and chests were purchased or built for the secure transport of such documents, and the 1636 guidelines for the council's operation called for transfers at the end of each year. ${ }^{16,17}$

At this point, however, I wish to turn from this aspect of archival operations to the question of how archives were used. I will concentrate on the official chronicles of Spain and historical studies on the Conquista of the Spanish Americas, which

\footnotetext{
13 Biblioteca del Monasterio de El Escorial, Ms. L. I. 12,2, fol. 188v .

14 Real Cédula, 30 June 1544, cf. Archivo General de Indias (Sevilla), Indiferente 427, L. 30, fol. $18^{\text {r }}$ $18^{\mathrm{v}}$.

15 Archivo General de Indias (Sevilla), Indiferente 426, L. 25, fol. 231 ${ }^{\mathrm{v}}$; Archivo General de Indias (Sevilla), Indiferente 428, L. 35, fol. $107^{\mathrm{r}}$. One 1658 deposition of documents from the secretariat for New Spain, covering material from 1595 to 1640, is well documented, cf. Archivo General de Indias (Sevilla), Indiferente 853 ((without pagination), Indice de los papeles que se remiten de la Secretaría de la N. España).

${ }^{16}$ Relevant fiscal receipts at Archivo General de Indias (Sevilla), Indiferente 426, L. 25, fol. $231^{\mathrm{v}}$. and Archivo General de Indias (Sevilla), Indiferente 426, L. 27, fol. 63 .

17 Recopilación, Lib. II, tít. vi, ley L bis LII.
} 
provide us the chance to reconstruct which documents inside and outside the archives became significant, that is, became politically 'hot'.

\section{Court chronicles inside and outside the archive}

On first glance, Spain's court historiographers-that is, royally privileged chroniclers-seem to have had a very comfortable position. Their privileges gave them access to sources and archives, and they were often personally acquainted with the political protagonists of their era. The official character of their offices and writings, however, significantly narrowed their range of options. Wherever they touched on the deeds or on the failures of individuals who were still present at court, whether personally or in the form of descendants, the historiographers' descriptions became matters not only of honor, but also of concrete political opportunities at court. Since all those participants were fully aware of this mechanism, the office of court historiographer always had a double character. On the one hand, it represented the dream of becoming a permanently financed historian raised above all his colleagues with unlimited access to the archives of the time; on the other hand, it represented the nightmare of permanent participation in and constraint from the very political events that the court historiographer was supposed to describe in a non-partisan way. In consequence, the extent of the official chroniclers' access to the archives should not simply be seen as a measure of their 'scholarly' quality or methodological possibilities. Rather, it was always also an indicator of their political standing. In other words, their privilege of 'open access' to the archive went hand in hand with the political restrictions of using these documents (Bermejo Cabrero 1980 , p. 409; Tate 1983 , pp. 40-41). ${ }^{18}$ The very practical way in which this applied will be shown below. For the moment, the key point is that official chroniclers felt that privileged access to the archives was a condition of their work, even if this privilege could not always be exercised fully and did not always enjoy the same importance (Navarro Bonilla 2003, pp. 96-105). In the case of early chronicles about the crown's American possessions, work in Simancas did not yet take on the same importance, since relatively few documents had transferred to Simancas and most of the protagonists were still present in court. The first chronicler of the Americas, Peter Martyr d'Anghiera, gained most of his information from his own work in the Council of Indies, or from conversation with Spaniards who had returned from the New World. Indeed, the residences of Peter Martyr and of the first president of the Council of the Indies, García de Loaisa, quickly became the most important sites for the exchange of information about the new lands. According to the Venetian ambassador Andrea Navagero in 1525, even though little was published about the Americas, one could encounter every kind of information at these houses, as well as the most marvelous objects (Navagero 1999, p. 50). The second chronicler appointed by the Council of the Indies, Gonzalo Fernández de Oviedo, was even further removed from archival research than Martyr in that he was not a member of the council and his seat was in Santo Domingo. His work rested,

\footnotetext{
18 The office of court historiographer in Castile was created by Ferdinand and Isabella.
} 
in essence, on conversation and correspondence, though he frequently cited the privileges he had received from Charles V: every magistrate, judge or officer in the Americas was obliged to report everything of historical importance to the chronicler, and such reports, notably, had to consist of official testimony, that is, authenticated copies by public scribes. Oviedo did complain, however, that his requests based on these privileges were often not fulfilled in a satisfactory way (Fernández de Oviedo 1992, vol. 1, p. 13; Gerbi 1992, p. 298).

The creation of a double office of chronicler and cosmographer for the Indies (cosmógrafo cronista mayor de las Indias) brought the principle of privileged source access to a high point. The new regulations for the Council of the Indies provided that the council scribe should hand over any papers the chronicler requested, against a receipt, so that the latter could carry out his charge more effectively. ${ }^{19}$ The chronicler, in consequence, not only gained the chance to view the actual records of the council, but also received access to the council's archive, which at this point still contained many valuable manuscript histories. These had been confiscated in multiple waves since the 1560s and allowed the chronicler to found his work on existing but unpublished works of history and geography (Baudot 1983, pp. 471-502). These changes thus gave the official chronicler after the 1570s a radically expanded access to the sources, since not only all existing archival material but also, so to speak, the entire Spanish world itself became available to him. All officeholders in the Americas were obligated to send information to the official chronicler and cosmographer. In addition, published lists of questions were repeatedly issued in order to gain comparable responses from a wide range of localities. New regulations for the council issued in 1636 expanded the chronicler's rights to access even further. Henceforth, they stated, the chronicler could inform the council whenever he discovered "any kind of papers, reports, histories or writings existing in the possession of private parties that might be important for what he was writing or intended to write" (Recopilación 1998, libro II, título 12, ley iii). The council was then obliged to collect the papers or make copies of them for his use.

It is therefore doubtless correct to see the cosmógrafo cronista mayor de las Indias as a historian who enjoyed unusually broad rights of access to sources. If one regards the actual writings of the men holding this office, however, it becomes clear that these rights did not increase their productivity. The first cosmographer and chronicler, Juan López de Velasco, concentrated entirely on geography and cosmography, producing no separate historical works. The office was divided after López de Velasco, and in 1591, Arias de Loyola was appointed as chronicler. Loyola was a far greater disappointment than his predecessor, and after three years, his salary was withheld because he had failed to produce the annual reports on the history of Spanish America that his appointment required. Loyola, who had not produced a single line, defended his productivity by claiming that the deadlines came into effect only after he had gathered all available papers and selected the ones he needed for his work. Although the material had been made available to him, its

19 Las Ordenanzas de 1571 del Real y Supremo Consejo de las Indias (1957), 49 (§ 122). 
extent and diversity had made it impossible to begin writing. ${ }^{20}$ Only Loyola's successor, Antonio de Herrera, who held the office from 1596 to 1625, actually began producing the desired historical works. Between 1601 and 1615, he published his four-volume Historia general de los hechos de los castellanos en las Islas $i$ Tierra Firme del Mar Oceano in Madrid. ${ }^{21}$ Among later official chroniclers of the Indies, Antonio de León Pinelo deserves mention, who spent his youth in Peru before working in the Council of the Indies first on the codification of laws, then as a Relator and after 1658 as chronicler. ${ }^{22}$ By the time of his final appointment, most of his research was already completed, including projects carried out in the Simancas archive, where he had examined material relating to codification, but also to the general history of the Spanish Indies, as early as $1626 .{ }^{23} \mathrm{~A}$ report he authored described the Sala de Indias as containing seventeen chests (arcas) containing some 400 bundles of documents. Another smaller chest was located in the room reserved for church patronage (sala de patronazgo). Because the collection lacked any inventory whatsoever, León Pinelo had to create his own inventory of the bundles, a project that took him six days of six hours each in the archive. His inventory throws a spotlight onto conditions at Simancas in the year 1626, but reveals less about his methods as a historian or on the significance of the documents he found. ${ }^{24}$ To probe such questions, we must turn back to the work of court chronicler Antonio de Herrera in the final section of this paper.

\section{Historical truth and public archives}

Antonio de Herrera did not belong to the category of historians "who die before they ever write anything." 25 Instead, he drew on the entire palette of possibilities open to the historiographer of the Council of the Indies. His Historia general de los hechos de los castellanos consisted largely of transcripts from the manuscripts that the council had earlier confiscated and 'archived', including the Historia general de las Indias by Bartolomé de las Casas, and the chronicle of Cieza de León (Ballesteros y Beretta 1934, pp. LXIV-LXXIX). Herrera also made use of the manuscript Sumario produced by his predecessor Juan López de Velasco, along with the maps it contained. After adding a few insignificant annotations, Herrera simply placed it at the beginning of his own historical account (Arocena 1963,

\footnotetext{
${ }^{20}$ Consulta, 8 April 1594, cf. Archivo General de Indias (Sevilla), Indiferente 742, n. 153, fol. $1^{\mathrm{r}}$; Consulta, 8 April 1594 (Archivo General de Indias (Sevilla), Indiferente 742, n. 153a).

21 On account of its division by decades, this work also circulated under the title Décadas.

22 Muro Orejón (1960), 1-4; appointed on 9 June 1658, sworn in on 15 July 1658. Cf. Archivo General de Indias (Sevilla), Indiferente 874 (without pagination).

23 On León Pinelo's archival work in October 1626, see Biblioteca Nacional de España (Madrid), Ms. 2939, fol. $179^{\mathrm{r}}$.

24 Biblioteca Nacional de España (Madrid) Ms. 2939, fol. 179 . References concerning access to documents from Simancas are also found in the papers of secretarial assistant Juan Díez de la Calle, cf. Biblioteca del Palacio Real (Madrid), Ms. II/2061.

25 Juan López de Velasco wrote derogatively in a memorial to Philip II. about the sort of chronicler who „se muere sin dexar escripta letra“, cf. Biblioteca Francisco Zabálburu, Altamira 159, D. 107.
} 
p. 37). Herrera also ordered the purchase of further manuscripts; for example, the nieces of Francisco Cervantes de Salazar received forty ducats after his death in exchange for handing over the manuscript of the Crónica de Nueva España. ${ }^{26}$ Evidently, Herrera drew primarily on the unpublished works of earlier historians that had been collected in the council's archive, rather than on archival material in the narrower sense. He also avoided discussing more recent historical events altogether. Nevertheless, even though the current generation had been excluded, a royally authorized history of the "deeds of the Castilians in the Indies" drew considerable attention-so much so, indeed, that the author was soon publicly attacked and cited before the courts. The plaintiff was Francisco Arias Dávila y Bovadillo, Count of Puñonrostro, who was a councilor on the royal Council of War and grandson of the conquistador Pedrárias Dávila. ${ }^{27}$ Dávila has been regarded up to the present as particularly brutal, since he is believed to have carried out systematic massacres of the indigenous population or at least to have allowed such massacres. He also had his son-in-law Vasco Núñez de Balboa, the Spanish discoverer of the Pacific, locked in a cage and then beheaded. Puñonrostro, however, denied all accounts that his grandfather had been a particularly bloody conquistador and sought to restore his family's honor through the courts. ${ }^{28}$

Puñonrostro's first attack took the form of a pamphlet accusing Herrera of being "false, meretricious, and disrespectful," which was soon followed by an eighteenmonth lawsuit against the royal chronicler of the Americas. ${ }^{29}$ The case provides useful insights into contemporary conceptions of how documents and archives should be used. For example, Puñonrostro pointed to procedural failures on Herrera's part as a way to refute his work. The chronicler had gained irregular access to the plaintiff's papers, he accused, by receiving them from a secretary before a complete and authenticated register had been created. Consequently, they should be transferred back across the street from the chronicler's house to the count's. ${ }^{30}$ Herrera responded by adducing the privileges and obligations of his office, which prevented him from removing any papers from his collection at the behest of a private citizen. Moreover, he argued, it would be improper to deprive a defendant of the very material he needed to sustain his defense. Since his work had only reached the year 1531, a great deal remained to be done, and he was currently occupied with "studying the papers with great labor, reviewing, glossing, sorting and comparing them." 31 To deny him the papers in question at this point would be to deny him his very office. Later in the case, Puñonrostro himself requested papers

\footnotetext{
${ }^{26}$ Cf. the Real Cédula of 16 Oct. 1597, Archivo General de Indias (Sevilla), Indiferente 427, L. 31, fol. $29^{\mathrm{v}}$., and Portuondo (2009), 147.

${ }^{27}$ Documents concerning the trial are located in the Archivo General de Indias (Sevilla), Escribanía 1012A and in Archivo General de Indias (Sevilla), Patronato Real 170, r. 19. A partial selection is published in Colección de documentos inéditos (1882, vol. 37).

28 „defender mi justicia y la honrra de mi casa“, letter of Count Puñonrostro, 9 Sept. 1602, Archivo General de Indias (Sevilla), Escribanía 1012A, 3.

${ }^{29}$ Archivo General de Indias (Sevilla), Patronato Real 170, r. 19, doc. 30, En el nombre de la Santissima Trinidad.

${ }^{30}$ Archivo General de Indias (Sevilla), Escribanía 1012A, fol. $1^{\mathrm{r}}-24^{\mathrm{r}}$.

${ }^{31}$ Antonio de Herrera, 26 Sept. 1602, Archivo General de Indias (Sevilla), Escribanía 1012A, 7, fol. $1^{\mathrm{r}}$.
} 
from Simancas to reinforce his case. He placed into evidence various documents, such as letters from Pedrárias Dávila to his wife that presumably came from private collections. Notably, this struggle over the proper description of the conquistadors and their deeds was consciously carried out in public, and both parties printed and circulated pamphlets laying out their positions. ${ }^{32}$ In order to reinforce his position on Pedrárias Dávila's brutality, Herrera also drew on the statements of earlier historians. This was not difficult since he had already made heavy use of Las Casas's unpublished Historia, which put great emphasis on the conquistadores' violence. Moreover, concentrating on a single example of particular gruesomeness suited the royal historiographer's purposes, since it allowed him to divert any claims of general responsibility on the part of the kings and the nation. As Herrera made clear in the printed debate, the task of the court chronicler was to allow no doubt that the Kings of Spain had conscientiously carried out their mission as described in the bulls of Pope Alexander VI. ${ }^{33}$ Any other outcome, as Herrera stated with some pathos in another pamphlet, would put the "reputation of Spain" at risk. Should Puñonrostro's case succeed, the foreign nations would no longer believe any reports coming out of Spain, since they would assume that the king's subjects were not allowed to speak freely. Additionally, a further wave of accusations against "chroniclers living and dead" should be expected. ${ }^{34}$ A letter of Herrera's from this period expresses his strategy of burdening a single, particularly brutal conquistador with the historical guilt of the period with even greater clarity: "if one attempts to save Pedrárias, then it would seem that the most Catholic kings consented to the violation of their own most pious orders, which never was and never will be the case." 35 In consequence, even Theodore de Bry gained the honor of being cited as an authority by a Spanish historian of the colonial enterprise. ${ }^{36}$

In an effort to determine whether and how such a case might be resolved, expert opinions were ordered, including one from the Collegium Hispanicum in Bologna that began by establishing that the chief duty of a historian must be to represent events in a precise and truthful way. ${ }^{37}$ Herrera himself was willing to be more conciliatory, as revealed by some notes that recorded his response to the Count of Puñonrostro's demands. They recorded his conviction that the historian "acted as a judge in his work," but also offered the count's party that he might "under appropriate circumstance make some of the passions milder," though without changing the substance of his account. Rather than that, Herrera noted, he would

\footnotetext{
32 See the dossier „Los papeles que ha pedido el conde de Puñonrostro de Simancas“, Archivo General de Indias (Sevilla), Patronato Real 170, r. 19 (without pagination).

33 Archivo General de Indias (Sevilla), Patronato Real 170, r. 19 (without pagination): In nomine sanctissimae Trinitatis. Lo que Antonio de Herra dize a los apuntamientos contra la historia de las Indias.

34 Archivo General de Indias (Sevilla), Patronato Real 170, r. 19 (without pagination): En la causa de la historia de las Indias se dize lo siguiente.

35 Archivo General de Indias (Sevilla), Escribanía 1012A, 23, fol. $1^{\mathrm{r}}$.

36 Archivo General de Indias (Sevilla), Patronato Real 170, r. 19 (without pagination), Caso que se consulta en conciencia, fol. $1^{\mathrm{r}}$.

37 Archivo General de Indias (Sevilla), Patronato Real 170, r. 19 (without pagination). In nomine IHS.
} 
prefer to be torn into a thousand pieces. ${ }^{38}$ Herrera also asked that the plaintiffs consider his position, namely that:

he defended the truth and the honor of the most Catholic Kings, of the nation, and of the royal council, who had given him the privilege of publishing this history; and that it would be more just to load all the cruel deeds and sins committed in the Americas on those who committed them, rather than on the kings who deserved no blame for them, nor on the whole nation. ${ }^{39}$

The verdict was announced on 19 September 1603. The judge, Gil Ramírez de Arellano, determined word-for-word how Herrera's book could speak about Pedrárias Dávila. ${ }^{40}$ The fact that the verdict largely supported Herrera's position should not be interpreted as an early victory for historical 'science', however. In fact, Arellano and Herrera were acquainted and valued each other's work. Herrera praised Arellano in a work on historical method as a supporter of history, while Arellano appointed the chronicler some ten months after the trial to censor a work for which Miguel de Cervantes had requested permission to publish, namely Don Quixote (Herrera 1804, p. 49; Bouza Álvarez 2008). Moreover, we can see what Herrera meant by "appropriate circumstances for making the passions milder" by examining his actions when compiling his Historia del mundo. The book portrayed the actions of Alessandro Farnese in a positive light — but only after two middlemen had confronted Farnese's son Ranuccio, who sought a career in court, with several compromising documents about his father's behavior. After payment of a suitable sum, the documents played no further role in the Historia; instead, Rannuccio read along for entire sections as his father's historiographical representation was crafted. A final payment was agreed upon, as well, should the volume reach a satisfactory conclusion. From Herrera's contemporaneous correspondence with one of his middlemen, we can see that he considered this procedure to be both customary and appropriate, since other princes had paid up to 1000 scudi (Ballesteros y Beretta 1934, pp. XXXVIII-L).

The conflict between Herrera and Puñonrostro is interesting not least because it makes visible the status that archives and archived documents took on during the trial's course. Herrera repeatedly argued that his description of the conquistador Pedrárias Dávila corresponded to the nine other historical works that had been published during the previous half century. ${ }^{41}$ For Puñonrostro, however, this fact was evidence of Herrera's negligence. The expert opinion from the jurists in Bologna, meanwhile, which generally supported Herrera's position, determined that the burden of proof lay with Puñonrostro, since he was the plaintiff and Herrera the defendant. Such proof was difficult to deliver, since the facts in question lay more than a century in the past, and witnesses could no longer be interrogated. If one

\footnotetext{
38 Archivo General de Indias (Sevilla), Patronato Real 170, r. 19 (without pagination), Lo que se responde a la pretension del conde de Puñonrostro.

39 Archivo General de Indias (Sevilla), Patronato Real 170, r. 19 (without pagination).

40 Archivo General de Indias (Sevilla), Patronato Real 170, r. 19 (without pagination), En la Ciudad de Valladolid.

41 Archivo General de Indias (Sevilla), Escribanía 1012 A, fol. $7^{\mathrm{r}}$.
} 
considered the three possible forms of proof (probanzas), all three spoke for Herrera. The first probanza lay in the letters and papers left behind by the two bishops of Chiapas and Darién (namely Bartolomé de Las Casas and the Franciscan Juan de Quevedo). It was impossible to maintain that two bishops, both of whom reported the murders and other crimes of Pedrárias Dávila, would have lied to their king about such important matters. The second probanza consisted of the many history books that had already been published. These had gained recognition through the licenses that allowed their publication, through the approbation of later historians, and not least because they enjoyed general acceptance. ${ }^{42}$ The expert opinion named as the third proof the documents that had been found in the "archives of the secretaries," in register volumes and protocols and in the archive of the Collegium of San Gregorio in Valladolid, and which had been delivered to the chronicler on royal orders. ${ }^{43}$

The evidentiary value of this archival material was then further scrutinized according to the standard arguments used in legal procedure. Where no testimony (testes) was available, the plausibility of other kinds of evidence (instrumenta) required careful scrutiny. The expert opinion tended to emphasize the argument that each document's resting place could serve as a decisive criterion for its value in a trial. A private charter, for example, could enjoy as much credibility as a public charter if it had been retrieved from a "public archive" (archivum publicum). ${ }^{44}$ In this context, publicus referred not to the public accessibility of an archive, but rather its establishment by a public authority, such as a magistrate or a court. According to the expert opinion's perspective, therefore, it was of no significance whether a particular text came from the archive of a secretary, the archive of a religious order, or perhaps the registers of the Council of the Indies. The archive at Simancas, which Herrera had not consulted, was not even mentioned. The opinion concluded by raising the point that Pedrária Dávila's descendants had never before this case raised any objections to their ancestor's representation in historical works, an omission that could be interpreted as meaning that they had intentionally allowed sufficient time to pass that it was no longer possible to find living witnesses who might establish the truth of the matter. Their previous silence suggested they had an interest in forgetting (olvidar). ${ }^{45}$

Although Herrera's own arguments did not directly refer to archival work, he repeatedly evoked "royal papers" (papeles reales). ${ }^{46}$ Two manuscript lists demonstrate that most of his documents came from the Council of the Indies, with

\footnotetext{
${ }^{42}$ Archivo General de Indias (Sevilla), Patronato Real 170, r. 19 (without pagination), In nomine IHS, fol. $1^{\mathrm{r}}$.

${ }^{43}$ San Gregorio was mentioned because it was the location of Las Casas' Historia de las Indias before it was delivered to the Council of the Indies' chronicler. Cf. Archivo General de Indias (Sevilla), Indiferente 426 , L. 25 , fol. $134^{\mathrm{v}}-135^{\mathrm{r}}$.

44 The quotations include one from the Codex Iustinianus, lib. IV, tit. XXI: "Charta quae profertur ex archivo publico testimonium publicum habet." Archivo General de Indias (Sevilla), Patronato Real 170, r. 19 , In nomine IHS, fol. $2^{\mathrm{r}}$.

45 Archivo General de Indias (Sevilla), Patronato Real 170, r. 19, In nomine IHS, fol. $3^{\mathrm{r}}$.

${ }^{46}$ Archivo General de Indias (Sevilla), Patronato Real 170, r. 19, doc. 30, En el nombre de la Santissima Trinidad.
} 
a few others coming from the king's holdings. And they reveal that Herrera had based his judgment almost entirely on complete historical works, rather than on primary documents. A note in these documents shows that even in documents for internal use, Herrera maintained that he had relied not on such historical works, but on the royal papers in drafting his own histories. ${ }^{47}$ In contrast, the pamphlets that Herrera published during the trial concentrated not on historical methods, but on the public legitimacy of his judgments: Puñonrostro's grandfather "had been no angel," and Herrera, in order "to protect the honor of the Castilian nation," had not included a hundredth part of the atrocities (vicios) that could be attributed to Pedrárias Dávila. ${ }^{48}$

How did the Count of Puñonrostro's party respond to the arguments found in the Bolognese expert opinion? They began by pointing out that Herrera's claim to be the defendant could be turned around; as a historian, he was in one sense primarily the plaintiff (actor), subject to an obligation to prove the truth of what he wrote. Next, the brief turned to the matter of the archivum publicum, defining in the process what the Bologna opinion meant by the 'archive of a secretary'; evidently, crucial documents for the case had been found in the desk of Juan de Ibarra, one of the king's most influential secretaries. ${ }^{49}$ The counteropinion maintained that one could not ignore the quality of the archive when discussing an archivo público; an archive only qualified as público if the documents it contained were preserved by persons officially charged to do. Moreover, the count would consider it fortunate if any living witnesses should emerge, since they would quickly show that Herrera had not proved and was unable to prove the truth of what he had written. ${ }^{50}$

Since Puñonrostro also ordered copies of documents from Simancas made during the course of the trial, it is important to ask how these were handled. Some nineteen documents were involved, whose contents relieved the count's grandfather of some responsibility. For example, Puñonrostro was able to present a real provisión that declared the conquistador innocent of charges raised during an investigation (residencia) about his exercise of office. The real provisión rested in turn on a verdict of the Council of the Indies from 1530. In addition, an investigative report had turned up in the archive that confirmed that Pedrárias Dávila had treated "his Indians" well. Puñonrostro did not fail to include the council verdict and other document extracts in pamphlets that he circulated at court; Herrera thus had to respond to the Simancas documents with a three-page pamphlet of his own, entitled A response to the papers against the Historia de las Indias that have recently been brought out of the archives in Simancas, as follows. ${ }^{51}$

\footnotetext{
${ }^{47}$ Archivo General de Indias (Sevilla), Patronato Real 170, r. 19, Memorial de Alonso de Mata and Los que han escrito en materia de las yndias.

${ }^{48}$ Archivo General de Indias (Sevilla), Patronato Real 170, r. 19, doc. 30, En el nombre de la Santissima Trinidad.

49 Archivo General de Indias (Sevilla), Patronato Real 170, r. 19, Jesus María (signed by the licenciado Fresno Delgado), fol. $1^{\mathrm{v}}$.

${ }^{50}$ Archivo General de Indias (Sevilla), Patronato Real 170, r. 19, Jesus María (signed by the licenciado Fresno Delgado), fol. $1^{\mathrm{v}}$.

${ }^{51}$ Archivo General de Indias (Sevilla), Patronato Real 170, r. 19, doc. 12, Lo que se responde a los papeles que contra la historia de las Indias que nuevamente se an traydo de los Archivos de Simancas lo siguiente.
} 
Herrera argued that the Simancas documents possessed only general relevance and could not function as evidence for the defense of Dávila. The positive verdict about the residencia had been issued under irregular circumstances, including intimidation. In the case of the treatment of the Indians, all of the witnesses had faced the same charges as Dávila himself, compromising their testimony. In addition, it was well known that "in the Indies, powerful men prove whatever they want." 52 Herrera's argument implied a general devaluation of administrative documents, which should not be taken simply as a tactical move. The royal court and the Council of the Indies were well aware that administrative processes could involve deception. The larger conclusion, rather, is that as official chronicler, Herrera had little interest in Simancas as a site for his work. He held a much more general concept of 'archive' and carried out his own historical practice primarily with unpublished manuscript histories from the archive of the Council of the Indies, out of which he could compile his own historical narratives. The expert opinion from Bologna rested on a similarly broad conception of the archives, one that in principle included any collection of documents maintained by a public instance. Only for the Count of Puñonrostro was the archive at Simancas truly important, since he saw it as giving him a chance to refute the case against his grandfather with documents that had been issued and stored by the royal authorities.

In this conflict, any scholarly use of the archive was merely an indirect and unintended consequence of the institutionalization of the office of court historian. Precisely because a "History of the deeds of the Castilians in the Indias" issued by the royal chronicler possessed greater authority than any other historical worksomething that everyone involved agreed on-it was necessary to struggle not only over the historical truth, but also over how suitable the negative or positive depiction of the conquistador might be. Archives became important in this dispute for tactical reasons rather than because of principles. Indeed, the whole case would probably never have gone to court had Puñonrostro simply bribed Herrera. Moreover, Herrera's openness to such bribes was far from unique, as shown in the case of the poet Lope de Vega. ${ }^{53}$ His view that papers in the archive were "worthless" and "dead" rested on his conviction that he could offer something better. Even before he became famous, he had profiled himself with a poem about Francis Drake, the Dragonata, which came out shortly after Drake's death. Drake had kept Spain on edge for years, but had been defeated once by the Spanish after the seizure of the Nombre de Dios. Lope de Vega must have known the details of these events well, probably through access to documents held by the Council of the Indies. Yet Vega's poem, in marked contrast to the actual records, described Diego Suárez de Amaya, rather than Alonso de Sotomayor, as the victor over Drake. He had obviously received money from the former. A memorial submitted to the Council of the Indies on 15 September 1599 protested this distortion of the actual events. Drafted by Antonio Herrera, the officially responsible chronicler, it protested

\footnotetext{
52 Archivo General de Indias (Sevilla), Patronato Real 170, r. 19, doc. 12, fol. $1^{\mathrm{v}}$.

53 On the bribery of the historiographers, see also Kagan (2004), p. 51.
} 
not the reversal of the true circumstances, but focused particularly on the damage this narrative might do to the reputations of people who had served during the victory (Wright 2001, pp. 24-32).

\section{References}

Arocena LA (1963) Antonio de Solis, cronista indiano. Estudio sobre las formas historiográficas del Barroco. Edición universitaria de Buenos Aires, Buenos Aires

Ballesteros y Beretta A (1934) Proemio. In: Herrera y Tordesillas A (ed) Historia general de los hechos de los Castellanos en las islas y tierrafirme del Mar Océano. Vol. I: Descripción de las Indias Occidentales. Tipografía de Archivos, Madrid, pp IX-LXXXVIII

Baudot G (1983) Utopía e Historia en México. Los primeros cronistas de la civilización mexicana (1520-1569). Espasa-Calpe, Madrid

Bermejo Cabrero JL (1980) Orígenes del oficio de cronista real. Hispania 40:395-409

Bouza Álvarez FJ (1996/97) Guardar papeles—y quemarlos-en tiempos de Felipe II. La documentación de Juan de Zúñiga. Reales sitios XXXIII: 2-15 and XXXIV: 18-33

Bouza Álvarez FJ (2001) Corre manuscrito. Una historia cultural del Siglo de Oro. Marcial Pons, Madrid Bouza Álvarez, FJ (2008) El primer lector del Quijote. ABC 846. 19 April 2008

Colección de documentos inéditos relativos al descubrimiento, conquista y organización de las antiguas posesiones españolas de América y Oceanía sacados de los archivos del reino y muy especialmente del de Indias (1882) vol. 37. Imprenta de Frías y compañía, Madrid

Fernández de Oviedo G (1992) Historia general y natural de las Indias. Edición y estudio preliminar de Juan Pérez de Tudela Bueso, vol 5. Biblioteca de Autores Españoles, Madrid

Gerbi A (1992) La naturaleza de las Indias Nuevas de Christóbal Colón a Gonzalo Fernández de Oviedo. Fondo de Cultura Económica, Mexico

Gómez Gómez M, González Ferrín I (1992) El archivo secreto del Consejo de Indias y sus fondos bibliográficos. Historia. Instituciones. Documentos 19:187-214

Herrera y Tordesillas A de (1804) Discursos morales, politicos e historicos ineditos, vol 1. Imprenta de Ruiz, Madrid

Instrucción para el gobierno del Archivo de Simancas (Año 1588) (1989) Estudio por José Luis Rodríguez de Diego. Ministerio de Cultura, Valladolid

Kagan RL (2004) El rey recatado. Felipe II, la historia y los cronistas del rey. Prólogo de Carlos Belloso. Universidad de Valladolid, Valladolid

Las Ordenanzas de 1571 del Real y Supremo Consejo de las Indias (1957) In: Antonio Muro Orejón (ed) Anuario de Estudios Americanos 14:363-423

Manzano Manzano, J (1973) El proceso recopilador de las Leyes de Indias hasta 1680. In: Recopilación de Leyes de los Reinos de las Indias, vol I. Ediciones Cultura Hispánica, Madrid, pp 9-67

Muro Orejón A (1960) Antonio de León Pinelo. 'Libros Reales de Gobierno y Gracia'. Contribución al conocimiento de los Cedularios del Archivo General de Indias (1492-1650). Escuela de Estudios Hispano-Americanos, Sevilla

Navagero A (1999) Cartas de micer Andrés Navagero. Gentilhombre veneciano a M. Juan Bautista Ramusio. In: García Mercadal J (ed) Viajes de extranjeros por España y Portugal. Desde los tiempos más remotos hasta comienzos del siglo XX, vol 2. Consejería de Educación y Cultura de Castilla y León, Salamanca, pp 47-62

Navarro Bonilla D (2003) La imagen del archivo. Representación y funciones en España (siglos XVI y XVII). Ediciones Trea, Gijón

Navarro Bonilla D (2004) Del corazon a la pluma. Archivos y papeles privados femeninos en la Edad Moderna. Ediciones Universidad de Salamanca, Salamanca

Páez de Castro J (1883) Memorial al rey don Felipe II sobre la formación de una librería. Revista de archivos, bibliotecas y museos 9:165-178

Portuondo MM (2009) Secret science. Spanish cosmography and the new world. University of Chicago Press, Chicago

Recopilación de leyes de los reynos de las Indias (1998) Mandadas imprimir y publicar por la magestad católica del Rey don Carlos II. nuestro señor. 3 vols. Imprenta nacional del boletín oficial del estado, Madrid 
Tate RB (1983) Alonso de Palencia y los preceptos de la historiografía. In: García de la Concha V (ed) Nebrija y la introducción del Renacimiento en España. Ediciones Universidad de Salamanca, Salamanca, pp 37-51

Wright ER (2001) Pilgrimage to Patronage. Lope de Vega and the court of Philip III, 1598-1621. Bucknell University Press, Lewisburg, London

\section{Author Biography}

Arndt Brendecke studied History at the University of Munich, where he received a Ph.D. in 1999 for his thesis on the idea of centuries and their transitions. His second book, focusing on the functions of knowledge in early modern Spanish colonial rule, was published recently under the title Imperium und Empirie. Funktionen des Wissens in der Spanischen Kolonialherrschaft (Cologne, 2009), and he recently co-edited a volume on information in early modern times, Information in der Frühen Neuzeit: Status, Bestände, Strategien (Münster, 2008). Brendecke has been a research assistant at the History Department of the University of Munich (2001-06), a visiting fellow of the Spanish Consejo Superior de Investigaciones Científicas in Madrid (2002-03), and now holds the chair of Latin American history and culture at the University of Bern. From 2006 to 2009, he was a Research Fellow (Dilthey Fellow) of the Fritz Thyssen Foundation. He is also a principal researcher of the Collaborative Research Center 'Pluralisierung und Autorität in der Frühen Neuzeit' at the University of Munich. 